Article

\title{
Energy, Seismic, and Architectural Renovation of RC Framed Buildings with Prefabricated Timber Panels
}

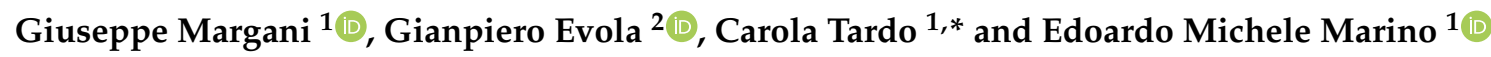 \\ 1 Department of Civil Engineering and Architecture (DICAr), University of Catania, via S. Sofia 64, \\ 95123 Catania, Italy; margani@unict.it (G.M.); edoardo.marino@unict.it (E.M.M.) \\ 2 Department of Electrical Electronic and Computer Engineering (DIEEI), University of Catania, \\ viale A. Doria 6, 95125 Catania, Italy; gevola@unict.it \\ * Correspondence: carola.tardo@unict.it; Tel.: +39-095-738-2509
}

Received: 14 May 2020; Accepted: 9 June 2020; Published: 13 June 2020

\begin{abstract}
In seismic European countries most of the residential building stock is highly energy-intensive and earthquake-prone because it was built before the enforcement of the most recent energy and seismic codes. Furthermore, this stock often shows a low architectural quality due to poor maintenance and/or construction and design deficiencies: for all these reasons, it needs deep renovation, but the use of common energy and seismic upgrading techniques is often unsustainable in terms of costs, work duration, and occupants' disturbance. Therefore, new integrated, affordable, fast, and low-disruptive renovation actions are strongly needed. This study proposes an innovative energy, seismic, and architectural renovation solution for reinforced concrete (RC) framed buildings, based on the addition of cross-laminated timber (CLT) panels to the outer walls, in combination with wooden-framed panels. The two panels integrate insulation and cladding materials in order to improve the energy performance and the architectural image of the renovated building. Moreover, the CLT panels are connected to the existing RC frame through innovative seismic energy dissipation devices. In case of an earthquake, these devices in combination with the CLT panels reduce the drift demand of the building, preventing or reducing structural damages and consequent repair costs. In particular, this paper investigates the technical feasibility, the energy efficiency, and the architectural enhancement of the proposed retrofitting system. To this purpose, dynamic thermal simulations were conducted on a typical multi-story residential building from the 1960s, located in Catania, Italy. The results indicated that this retrofitting technique considerably improved the energy performance of the selected building, with a reduction of the global energy demand up to nearly $60 \%$. The presented study is part of a larger research project aimed at also investigating, in a further stage, the seismic performance achievable by the above-mentioned renovation solution.
\end{abstract}

Keywords: integrated and sustainable renovation; cross-laminated timber; RC framed buildings; prefabrication; time and cost reduction; low-disruptive retrofitting

\section{Introduction}

The renovation of the existing building stock can lead to important energy savings and play a catalytic role in the decarbonisation of the planet. In Europe, residential and non-residential buildings are currently responsible for $40 \%$ of the final energy demand and for approximately $36 \%$ of greenhouse gas (GHG) emissions [1]. In 2017, the residential sector alone accounted for $27.2 \%$ of the final energy consumption; specifically, $64 \%$ of the energy consumption in households was related to space heating, mainly due to the low thermal insulation of building envelopes [2]. In fact, based on data from the Buildings Performance Institute Europe [3,4], 75\% of EU buildings and more than $80 \%$ of the residential ones were built before 1990, i.e., before the enforcement of most EU energy regulations for buildings. 
For instance, in Italy, according to the 2011 census of the Italian National Institute of Statistics (ISTAT), around $86 \%$ of the current residential stock was built before the issue of Law 10/1991, which is the first restrictive Italian regulation on the reduction of energy consumption in buildings. The U-value of the above-mentioned EU building envelope ranges from $2.07 \mathrm{~W} \mathrm{~m}^{-2} \mathrm{~K}^{-1}$ to $1.44 \mathrm{~W} \mathrm{~m}^{-2} \mathrm{~K}^{-1}$, leading to very low energy performance. Accordingly, the majority of the existing stock has to improve its energy efficiency in order to match the goals of the Energy Performance of Buildings Directive (EPBD). This action, in combination with the construction of new nearly-zero energy buildings, is expected to reduce by $80 \%$ the final energy demand for space heating, and by $90 \%$ the GHG emissions by 2050 [5].

At the same time, in EU seismic countries, the seismic safety of the existing buildings is also a critical issue. In fact, according to the European seismic hazard map (Figure 1), nearly $50 \%$ of the European territory is earthquake-prone. On the other hand, in countries with medium/high seismic hazard, like Italy, around 50\% of the residential stock has a high seismic vulnerability since it was built before the enforcement of seismic codes [6].

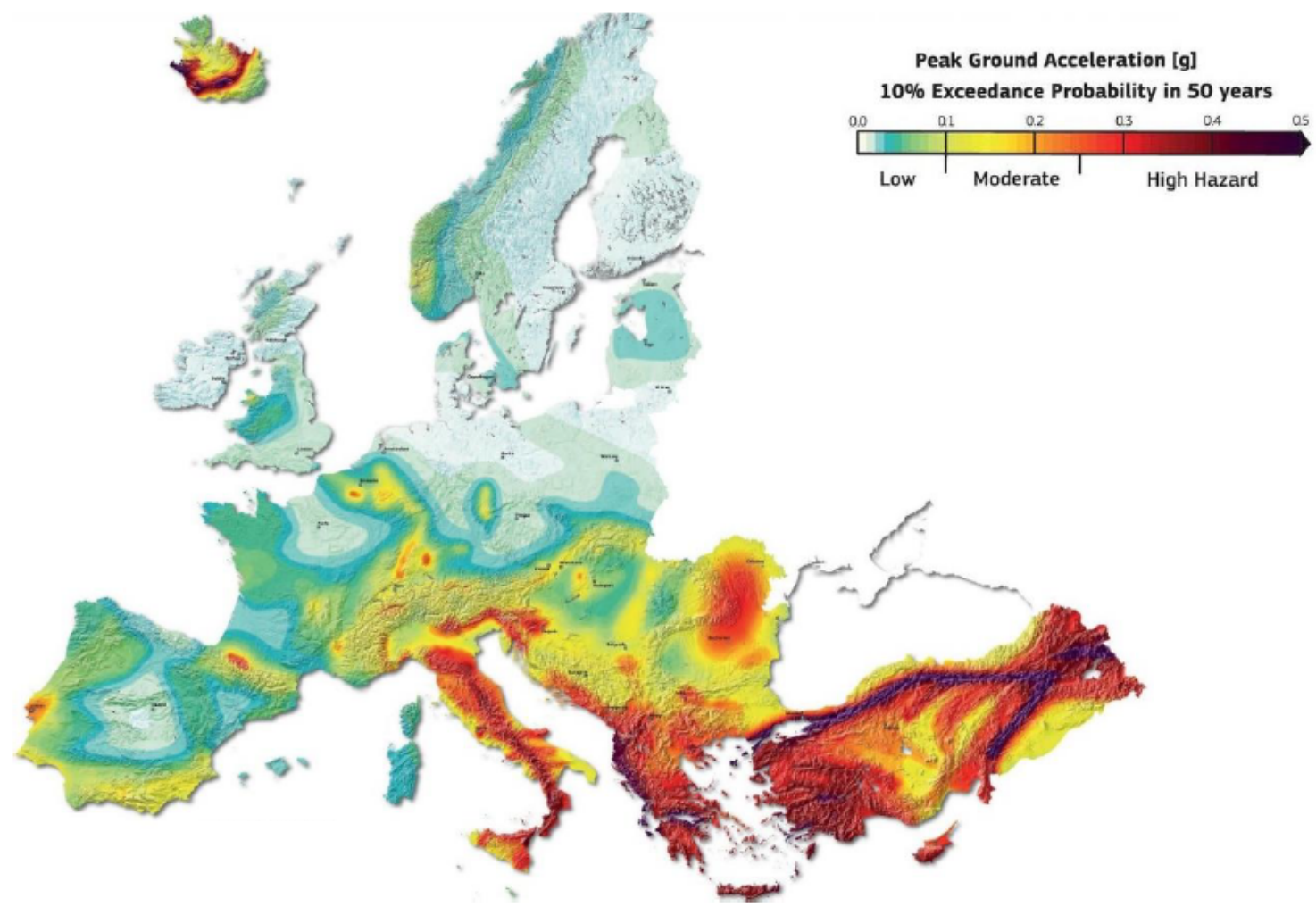

Figure 1. European seismic hazard map [7].

The framework depicted above evidences that most EU buildings are both highly energy-intensive and earthquake-prone.

Finally, in European countries, many buildings (around 35\%) are over 50 years old, which means that they have reached their nominal service life, exhibiting structural deficits for both vertical and horizontal loads [5], and often a low architectural quality due to poor maintenance. Therefore, in seismic countries, renovation solutions only aimed at reducing the energy demand will not prevent the human and economic losses caused by earthquakes (Figure 2). This turns out to be unsustainable, from a social, economic, and environmental point of view. In fact, the substantial environmental impact in terms of the carbon footprint associated with building repair or reconstruction after a seismic event should also be considered. In particular, Belleri and Marini [8] estimated that the expected annual embodied equivalent $\mathrm{CO}_{2}$ associated with seismic risk is equal to $87 \%$ of the annual operational $\mathrm{CO}_{2}$ after only energy retrofitting interventions. 


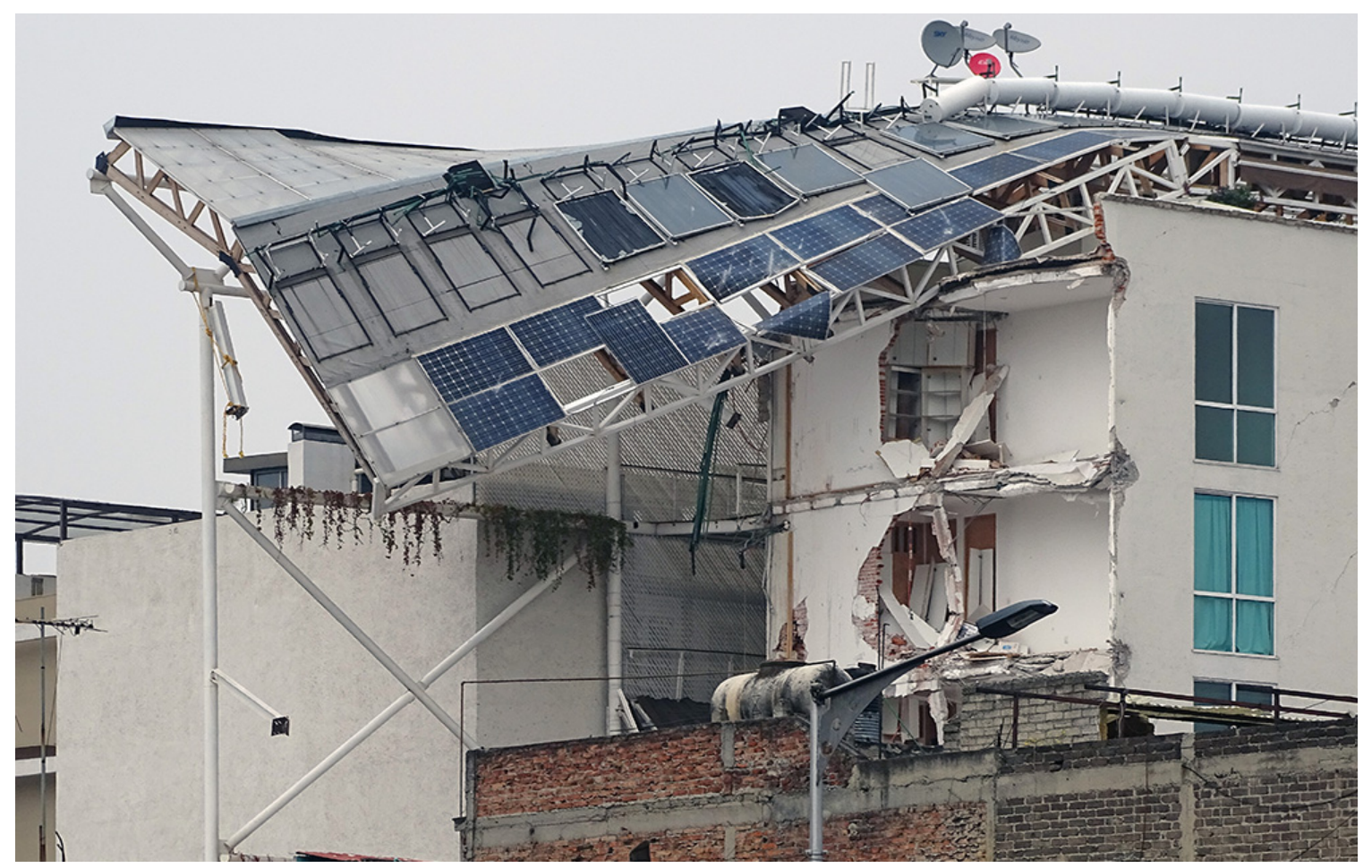

Figure 2. A 7-story building renovated only in terms of energy efficiency, partially collapsed after the earthquake that struck Mexico City in 2017 [9].

Consequently, in seismic regions, energy and seismic renovation actions must be combined. To do this, we have two options: to retrofit or to demolish and reconstruct the building. Generally, the first option entails lower embodied energy, global warming potential and economic impact, and shorter relocation time, thus proving to be more sustainable. Therefore, demolition and reconstruction should be preferred only if the building is in a very bad condition, and retrofitting solutions are not economically and technically advisable [10-12].

However, many barriers currently hinder the combined use of current energy and seismic retrofitting techniques, such as excessive costs, long time for implementation, and high occupants' disturbance. In particular, in Italy, the cost for energy and seismic retrofitting of apartment blocks built between the 1950s and 1980s currently ranges from 100 to $230 € / \mathrm{m}^{3}$ [7], i.e., from around 300 to $700 € / \mathrm{m}^{2}$, making these interventions poorly accessible to the owners, especially to the low-income families. Moreover, most combined renovation interventions require the occupants' relocation during the works, thus resulting in additional costs and disruption for temporary accommodation.

According to these remarks, new techniques based on integrated approaches are required in order to make combined renovation more sustainable-environmentally, economically, and socially-and less disruptive. In particular, more affordable renovation actions are needed in order to also ensure the building retrofitting needs of low-income households.

In this framework, this paper proposes and analyses an innovative integrated renovation solution for RC framed buildings based on the use of prefabricated timber panels. Specifically, the technical feasibility, the energy efficiency and the architectural enhancement potential of the proposed solution are here investigated. The presented study is part of an ongoing research project aimed at also investigating, in the following step, the seismic performance achievable by means of the above-mentioned renovation solution.

Firstly, to better understand the overall topic, a review of the state of the art of traditional and innovative energy and seismic renovation interventions for RC framed buildings is presented in the following section. 


\section{State of the Art of Traditional and Innovative Renovation Interventions for RC Framed Buildings}

\subsection{Combined Energy and Seismic Renovation Interventions}

Traditional solutions combine energy and seismic renovation interventions in an additive way.

The result is the superposition of two separate interventions, which can also be implemented separately, in distinct periods.

On the one hand, retrofitting solutions for reducing the building energy demand generally aim at increasing the thermal resistance of the building envelope through the application of insulating materials on walls and roofs, and through the installation of high-performing windows. Further solutions include the installation of sun-shading devices to control solar radiation, the adoption of passive-cooling strategies to exploit bioclimatic resources and the improvement of the efficiency of heating, ventilating, and air-conditioning (HVAC) equipment [7].

On the other hand, different strategies can be used for the seismic upgrading of RC framed buildings. One strategy consists of reinforcing part of the existing structural elements (columns and/or beams) while maintaining the original building frame system. Steel or RC jacketing is the most common traditional strengthening technique that involves the increase of the cross-section of resisting elements. The implementation of conventional jacketing requires intensive labor, accurate detailing, and relevant quantities of materials and is highly time-consuming and disruptive [13,14]. Instead, fiber-reinforced polymer (FRP) jacketing is a more recent solution based on the use of composite materials (carbon, aramid, fiberglass, etc.) embedded into organic resins. This system is corrosion-resistant, reduces implementation time, and allows preserving the geometry of the RC elements; however, FRP jacketing entails high costs, skilled labor, hazardous handling, bad fire behavior, poor behavior at high temperature, and cannot be applied at low temperature or wet surfaces, mainly due to the use of the organic resins $[15,16]$. To go beyond the FRP limits, researchers have recently introduced the textile-reinforced mortar (TRM), which combines textile fiber reinforcement with inorganic matrices, such as cement-based mortars [14,17]. However, jacketing interventions remain invasive and expensive as they require to isolate the $\mathrm{RC}$ members and the reconstruction of relevant portions of infill walls, cladding layers and-in some cases-mechanical systems.

Another strategy consists of creating a new seismic-resistant system connected to the existing building, while the original RC frame will resist only to gravity loads. The installation of new RC shear walls or steel-braced frames, located inside or outside of the building, are applications of this criterion that improves the global stiffness, strength, and plastic deformation redistribution capacity of the structure [18]. These strategies require relevant enlargement and reinforcement of the foundations, while the addition of external structures is not always possible.

An alternative seismic upgrading strategy is based on the reduction of the seismic demand of the structure through the installation of seismic isolators between the superstructure and the foundation. This intervention increases the fundamental period of the structure and in turn reduces the seismic forces it experiences [19]. Seismic base isolation is not always suitable for building retrofitting because it requires minimum distance limits between bordering buildings, is less effective for high-rise buildings, and entails high implementation costs.

\subsection{Integrated Energy and Seismic Renovation Interventions}

The development of solutions that combine energy and seismic renovation interventions in an integrated way, instead of an additive way (see the previous section), is a recent issue. Most of the related research focuses on new and innovative retrofitting technologies that require installation from the outside of the buildings, thus avoiding occupants' relocation and decreasing their disruption.

Bournas [20] suggested integrating the innovative TRM strengthening technique with the installation of insulating materials and heating systems from the outer side, for both structural and non-structural elements of RC framed or unreinforced masonry buildings. Another integrated and 
low-disruptive solution is the "Geniale cappotto sismico", recently introduced in the Italian building market by the company Ecosism S.r.1. [21,22]. This innovative system consists of adding to the existing building envelope a new earthquake-resistant skin, made up of a thin RC slab cast in situ between two or one pre-assembled layers of insulation materials. Nevertheless, the use of cement-based mortar and concrete makes both the above-mentioned systems less environmentally friendly and not reversible. One recent research study also investigated the replacement of the external layer of double-leaf infill walls with autoclaved aerated concrete (ACC) blocks in order to exploit the thermal and mechanical performance of this innovative construction material [23]. However, although this solution requires a significant economic effort, a full seismic upgrade of the building is unlikely to be achieved in high-seismicity areas.

Other studies proposed integrated solutions based on earthquake-resistant exoskeletons aimed at improving the structural safety of the existing buildings by increasing the overall stiffness and strength [24-27]. Specifically, Ferrante et al. [24] suggested the use of external steel bracings as structural support for a new energy-performing envelope consisting of pre-assembled components, which also create new additional and customized living spaces, thus increasing the building global value and the users' living comfort. Marini et al. [25] proposed a holistic renovation approach based on an engineered double skin consisting of different structural exoskeletons equipped with technological devices for the concurrent improvement of the energy efficiency and the architectural quality of the building. The aesthetic issue was also underlined by D'Urso and Cicero [26], who proposed to combine the use of parametric design and steel exoskeletons in order to generate multiple integrated retrofitting alternatives. A double-skin solution was also investigated in the study of Manfredi and Masi [27], where new infilled RC frames were externally added and connected to the existing RC structure to satisfy both thermal and seismic requirements. The volumetric increase of the existing buildings is the main limitation for the exoskeleton-based integrated systems: indeed, it is not always achievable due to lack of available perimetral space and legislative constraints.

A further recent integrated approach to building renovation is based on the use of cross-laminatedtimber (CLT) prefabricated panels $[28,29]$. CLT is an engineered wood product with high strength, stiffness, and dimensional stability due to the crosswise build-up [30]. It is also a good insulating material thanks to its low thermal conductivity $\left(0.10 \div 0.13 \mathrm{~W} \mathrm{~m}^{-1} \mathrm{~K}^{-1}\right)$ [31]. CLT panels coupled with a further insulation layer and finishing materials have been investigated in replacement of the existing masonry infill walls of RC framed buildings, with the main purpose of increasing the overall lateral stiffness of the structure, thus reducing the story drift demand [29]. The same integrated system has been also proposed in addition to the external walls, realizing the connection to the structure through special dissipative devices [28]. The external arrangement of CLT-based integrated systems well meets the current renovation requirements of quick installation, cost-effectiveness, low-disruption, use of low-carbon materials, and reversibility. However, these studies are at a preliminary stage, and the potential of the proposed systems should be further investigated.

\section{Materials and Methods}

\subsection{Energy, Seismic, and Architectural Renovation through Prefabricated Timber Panels}

The proposed retrofitting system is based on the idea of cladding existing RC framed buildings with a new performing skin made of pre-assembled and customizable components. Specifically, the system consists of adding prefabricated CLT structural panels to the existing outer walls by connecting them to the RC beams through innovative dissipative devices (Figure 3a). These devices are basically friction dampers that make available the additional lateral stiffness of the CLT panels and dissipate seismic energy in the occurrence of moderate and strong ground motions, respectively. Both these effects reduce the drifts demanded by earthquakes, reduce damage to non-structural and structural components, and improve the seismic performance of the RC frame. Furthermore, the activation of the 
damper defines an upper bound to the force sustained by the CLT panel, thus preventing its failure even under strong ground motions.

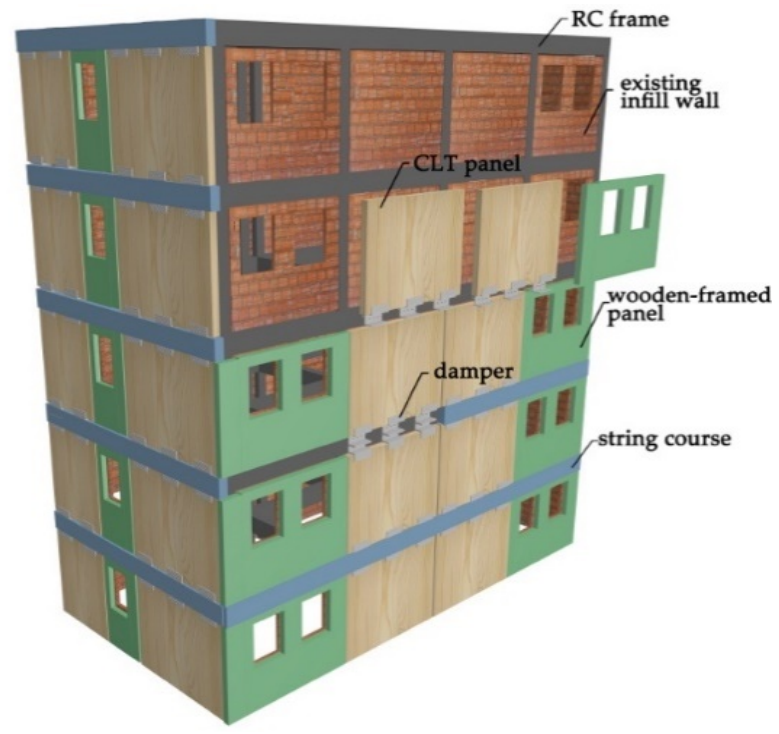

(a)

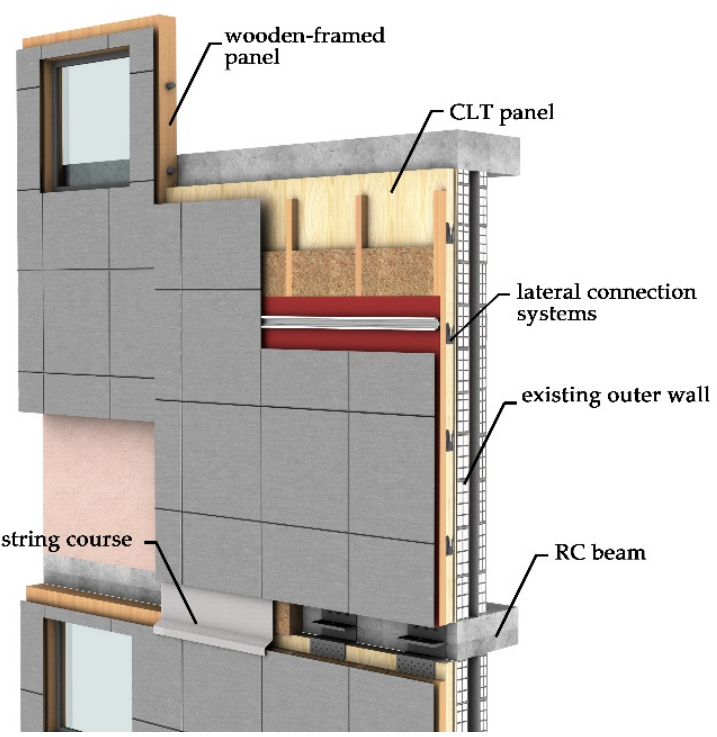

(b)

Figure 3. (a) Components of the proposed retrofitting system; (b) External installation of prefabricated timber panels with ventilated façade system. RC: reinforced concrete; CLT: cross-laminated timber.

The CLT structural panels are combined with non-structural pre-assembled panels, which are provided with high-performing windows that will replace the existing ones. Since the latter panels have no structural role, they are made of lightweight wooden frames in order to ensure easier manufacture and cost savings. Common concealed hook brackets can be adopted as lateral connection systems between the panels (Figure 3b). Both panels integrate bio-based insulation materials (e.g., hemp, cork, wood fiber, cellulose fiber, sheep wool, etc.) and the desired finishing layer (e.g., ceramic, wood, stone, glass, metal, PV modules, etc.). The renovation system is completed by cladding the RC beams with pre-assembled string courses to protect dampers and connections and to reduce thermal bridges. The result is a new performing envelope applied to the existing one that concurrently improves the energy, seismic, and aesthetic performance of the renovated building.

As illustrated in Figure 4, the damper consists of two steel profiles, which connect the CLT panels of two consecutive floors with the existing interposed $\mathrm{RC}$ beam. The upper profile is connected to the $\mathrm{RC}$ beam by anchor bolts. The bottom profile is provided with slotted holes and is connected to the upper one by pretensioned high-strength bolts. The shear force is transmitted from the upper to the bottom profile by means of the friction exerted in the contact surface. The number of bolts and the pretension force control the friction force. During an earthquake, when the force transmitted by the damper attains the value of the friction force, the upper profile slides on the bottom one dissipating seismic energy. The system is designed to allow a quick and easy external installation, to prevent damages for low- or medium-intensity earthquakes, and to be well adaptable to the most common RC framed buildings. For instance, in buildings with external RC flat beams and balconies, the upper profile could be fixed directly to the above overhang. The CLT panels are pre-assembled off-site with the upper profiles, while the bottom profiles are fixed on-site during installation in order to properly align and connect the friction surfaces of the two profiles. The damper inspection and maintenance are also eased by the string courses, which can be easily removed (Figure 3b). These string courses are designed to be connected only to the upper panels, thus allowing them to slide in case of an earthquake. The installation of both prefabricated panels requires the use of lifting equipment, thus avoiding the costs and time needed for the scaffolding set-up. The quick and easy installation also reduces 
the risk of errors and unexpected on-site delays as well as allows easy removal and replacement of all components.

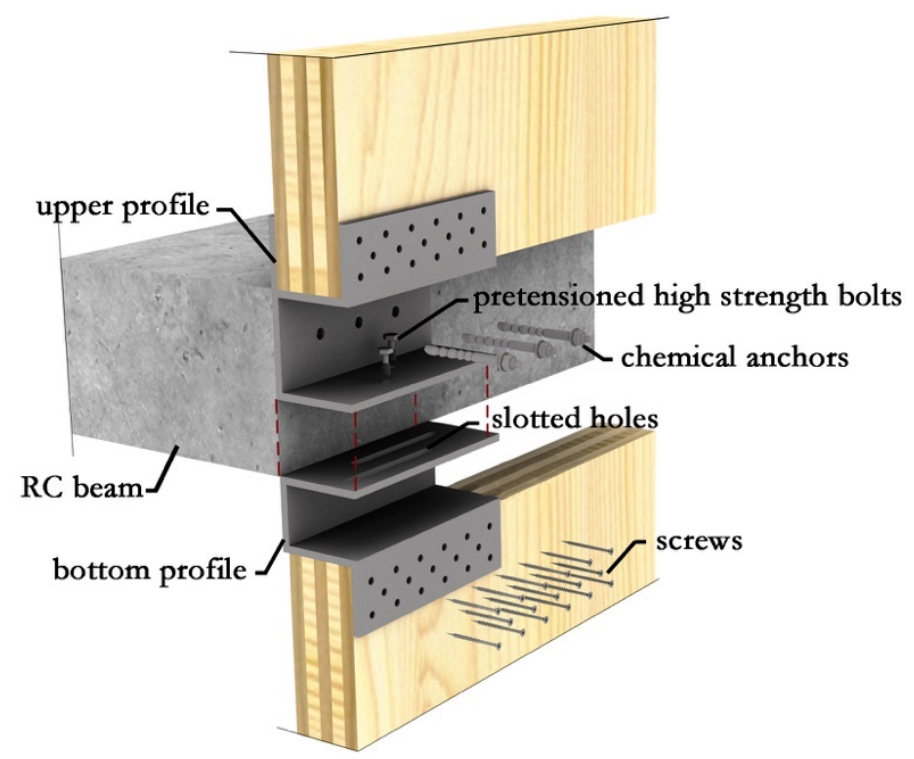

Figure 4. Proposed seismic energy dissipation damper (structural CLT panel is reported without insulation and cladding materials).

To sum up, the proposed retrofitting system represents an environmentally friendly solution, thanks to the use of prefabricated timber-based panels that will also integrate recycled and/or recyclable materials and components with low embodied energy. The use of pre-assembled components, the external installation, and the innovative damper configuration can also considerably reduce implementation time and occupants' disruption.

\subsection{The Case Study}

In EU seismic countries most of the existing buildings were built between the 1950s and 1980s due to the high housing demand of that period. Many public housings are among these. For instance, in Italy, around 800,000 public housing dwellings were built within that time [32]. Typically, these buildings are multi-story and multi-family (apartment blocks) and have RC structural frames (often one-way frames) with infill walls made of hollow clay bricks (Figure 5).

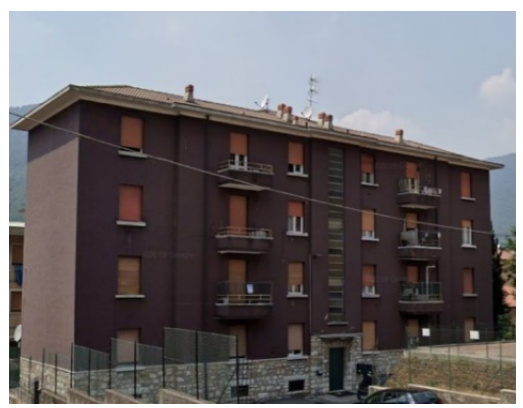

(a)

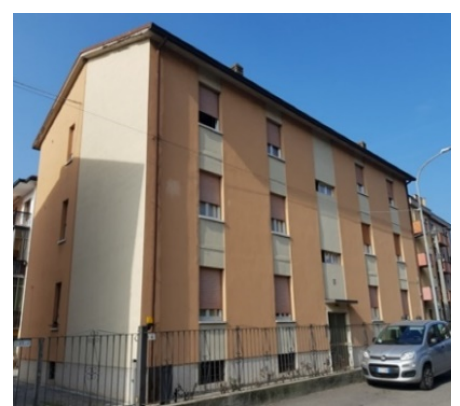

(b)

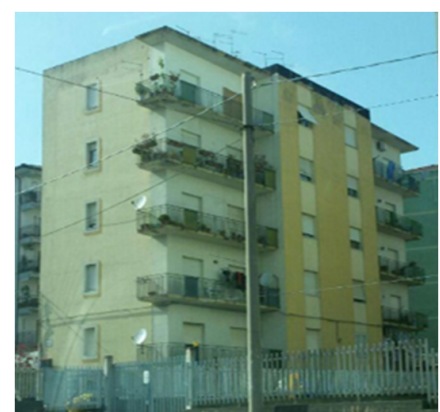

(c)

Figure 5. Typical RC framed apartment buildings located in: (a,b) Villa Carcina (Northern Italy, moderate seismic zone); (c) Acireale (Southern Italy, high seismic zone).

The building selected as the case study (Figures 6 and 7) is representative of the above-mentioned building typology. It is an RC framed apartment block built in 1968 and located in Via Don Carlo 
Gnocchi, in the city of Catania (Southern Italy). It consists of two blocks (named A and B in Figure 7) separated by a stairwell. The two blocks have 6 and 4 stories, respectively, with a total number of 16 apartments. In Block A, there is also an attic, and the first story is used as a cellar. The external infill walls are made of two leaves of hollow clay bricks. Poor maintenance and improper additions made by owners or tenants have altered the original architectural identity. For instance, most of the original recessed balconies in the main façades have been enclosed with PVC framed windows.

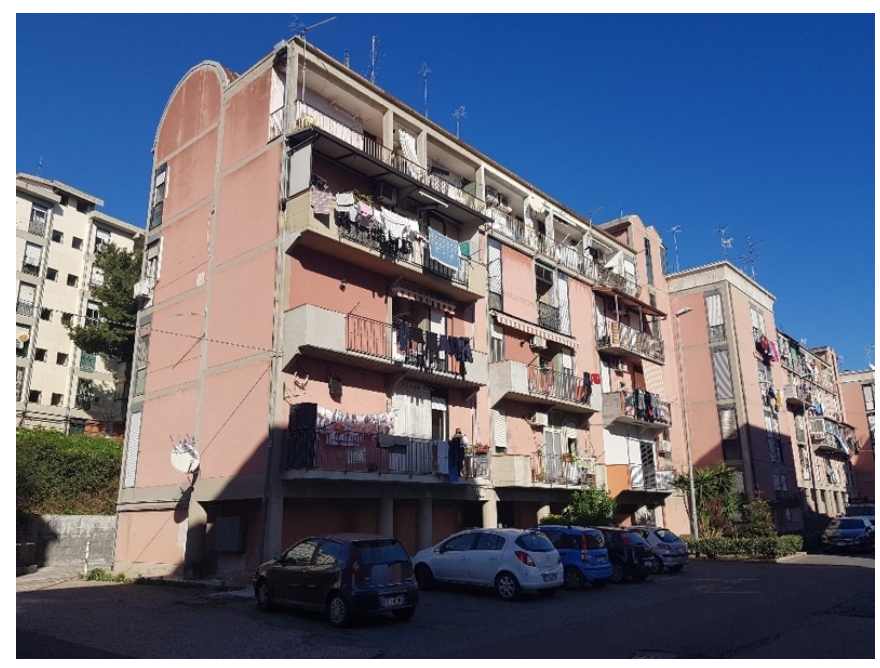

Figure 6. Multi-story apartment building selected as the case study.

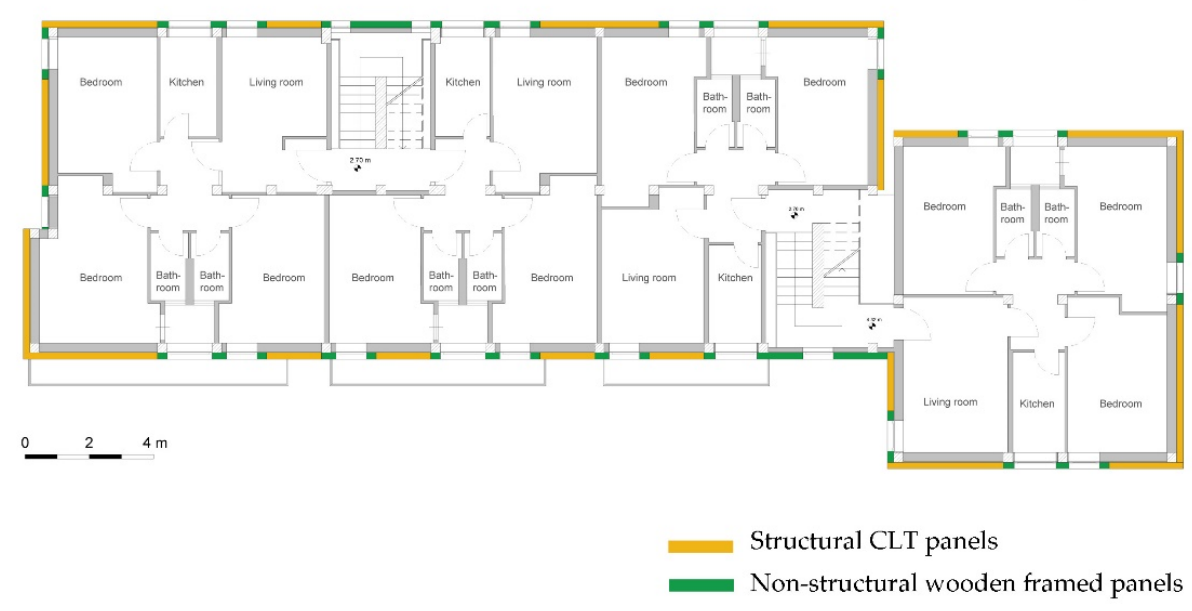

Figure 7. Typical plan of the case study after the application of the proposed integrated retrofitting system.

The proposed integrated renovation intervention was virtually tested for the re-cladding of the selected building. CLT panels were designed for the blind façades, while wooden-framed panels with integrated double-glazing windows were used for the glazed portions of the façades. Figure 7 shows the plan layout of the typical floor of the case study building after retrofitting.

Regarding the improvement of the architectural image of the case study, Figures 8 and 9 report three possible design solutions in order to show the aesthetic potential and versatility of the proposed retrofitting system. In particular, the pictures display the use of prefabricated timber panels cladded with wooden boards (Figures 8 and 9b), metallic sheets (Figure 9c), and plastered cement boards (Figure 9d). The metallic cladding entails higher costs but reduced maintenance, while the wooden and plaster ones are less expensive but need more frequent maintenance; moreover, wooden claddings 
generally are more resistant in case of accidental collision during the installation of the panels on-site. External sun-shading devices to control solar radiation were also included to verify their effective architectural integration. The proposed shading devices, which are variably colored in Figure 8, slide horizontally on metallic trails fixed at the string-course level.

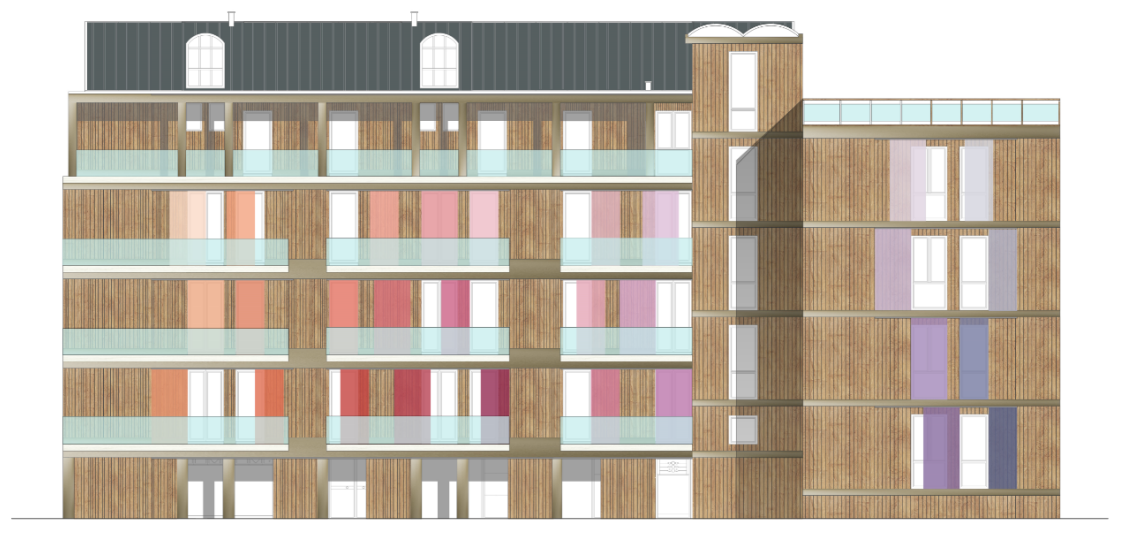

Figure 8. South front of the case study building after the application of prefabricated timber panels cladded with wooden boards.

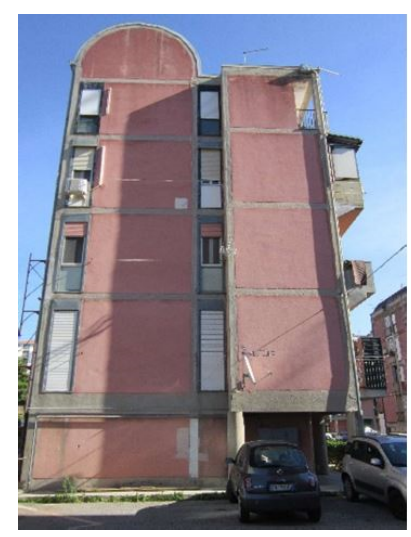

(a)

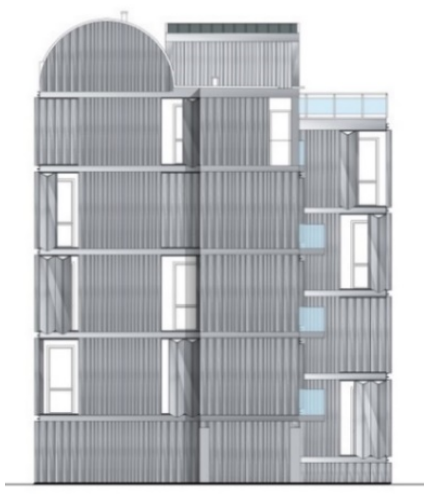

(c)

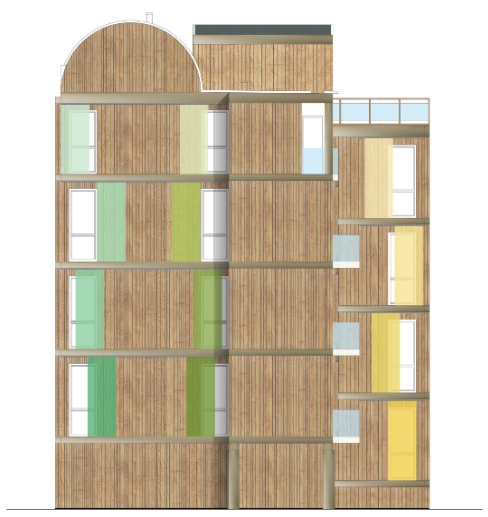

(b)

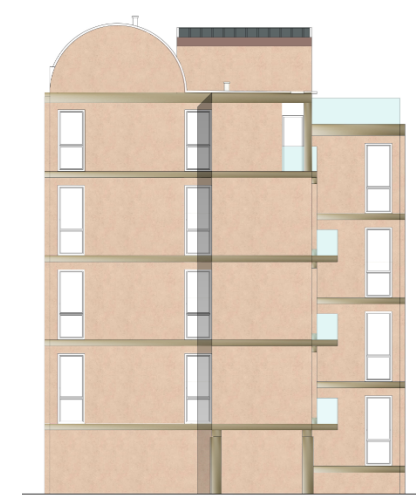

(d)

Figure 9. West front of the case study building at (a) the current state and at the possible post-renovation state, after the application of different cladding materials: (b) wooden boards; (c) metallic sheets; (d) plaster. 


\subsection{Dynamic Thermal Simulation}

The two blocks were parametrically modelled in Grasshopper, based on geometrical models on Rhino, and dynamic thermal simulations were conducted through Honeybee and Ladybug plug-ins for Grasshopper, by considering the pre- and post-renovation states.

In the model, each room corresponds to a thermal zone, except for the two adjacent bathrooms that were modelled as a single thermal zone. The fourth story of Block A was not modelled because it is located between two heated stories and shows the same behavior as the third story. The attic and the first story of Block A and the enclosed recessed balconies on the façades were also defined as thermal zones. Two different strategies were adopted to simulate the heat transfer between heated spaces (residential units) and unheated spaces (stairwells, enclosed recessed balconies, attic, and cellars). In particular, the "Honeybee_Create EPPlenum" component was used to simulate enclosed niches, attic, and cellars as spaces with no internal loads, and the "Honeybee_create HBsurface" component with "adiabatic" condition was assigned to the wall surfaces bordering the stairwells. The urban context was also geometrically modelled to simulate the shading effect of the surrounding buildings (Figure 10).

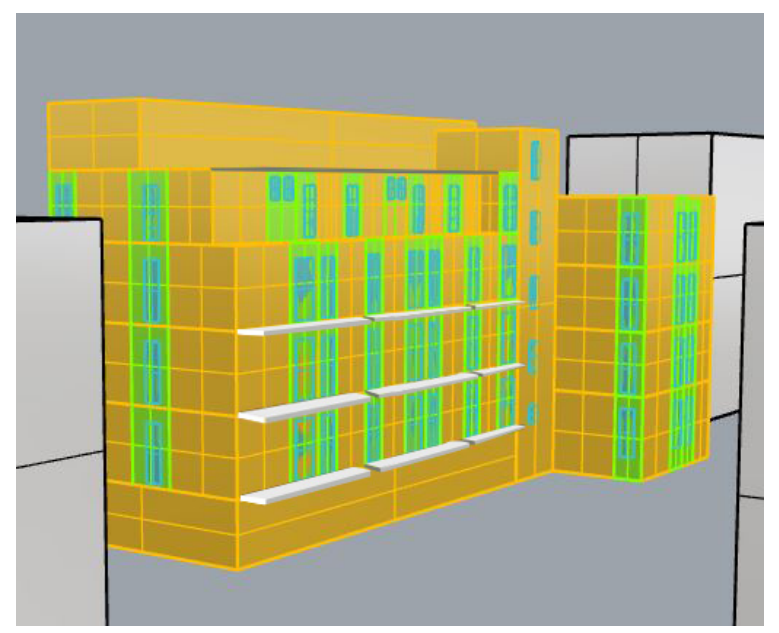

(a)

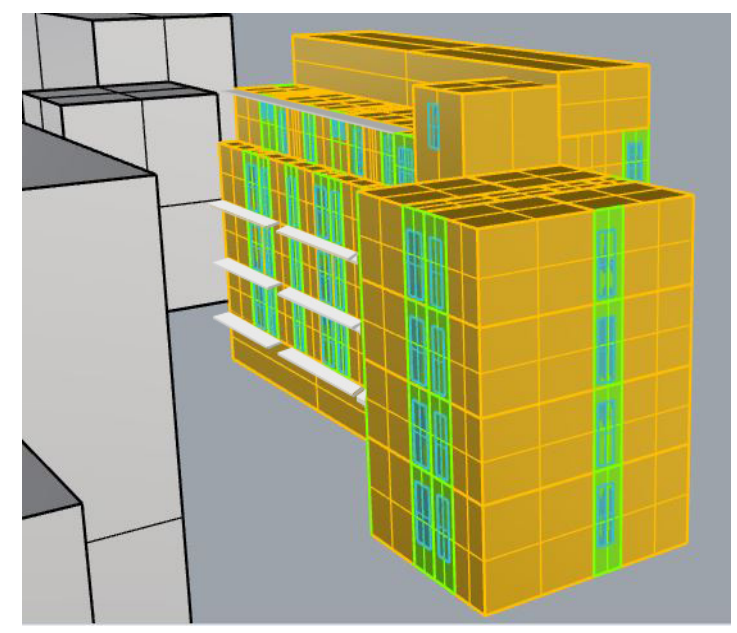

(b)

Figure 10. (a,b) 3D model of the selected building in Grasshopper on Rhino (post-renovation).

Regarding the thermal features of the building components, the following materials were considered for the simulations. In the current state, the external infill walls were made of two leaves of hollow clay bricks (8-cm-thick internal leaf and 12-cm-thick external one) with an intermediate air cavity (4.5-cm-thick) without thermal insulation. Attic floor (Block A), flat roof (Block B), and internal floors were characterized by RC and hollow tiles mixed slabs (24-cm-thick), without thermal insulation too. The windows had steel frames (with no thermal break), single glazing, and external roller shutters as shading systems; only the most recent windows installed in the recessed balconies had PVC frames and double glazing.

In the post-renovation state, the first simulation was conducted by assuming the adoption of the proposed integrated retrofitting system based on prefabricated timber panels (here abbreviated PTP). Specifically, the outer walls of the building included a further layer of structural 10-cm-thick CLT panels $\left(\rho=420 \mathrm{~kg} \mathrm{~m}^{-3} ; \lambda=0.12 \mathrm{~W} \mathrm{~m}^{-1} \mathrm{~K}^{-1}\right)$ coupled with a 6.5 -cm-thick wooden fiber insulation layer $\left(\rho=50 \mathrm{~kg} \mathrm{~m}^{-3} ; \lambda=0.038 \mathrm{~W} \mathrm{~m}^{-1} \mathrm{~K}^{-1}\right)$ in combination with non-structural wooden-framed panels made up of 10 -cm-thick high-density wooden fiber insulation $\left(\rho=120 \mathrm{~kg} \mathrm{~m}^{-3} ; \lambda=0.038 \mathrm{~W} \mathrm{~m}^{-1} \mathrm{~K}^{-1}\right)$ and an air cavity (6.5-cm-thick). Two different cladding materials are proposed for both prefabricated panels, namely plaster and wood, with an additional 2-cm-thick air cavity in the latter case (Figure 11a,b). 


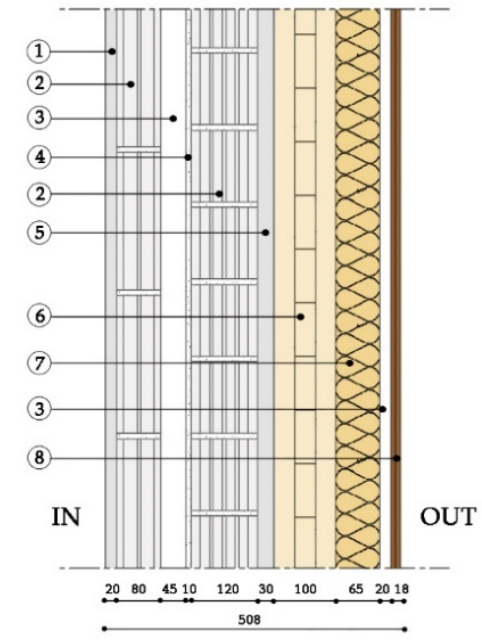

(a)

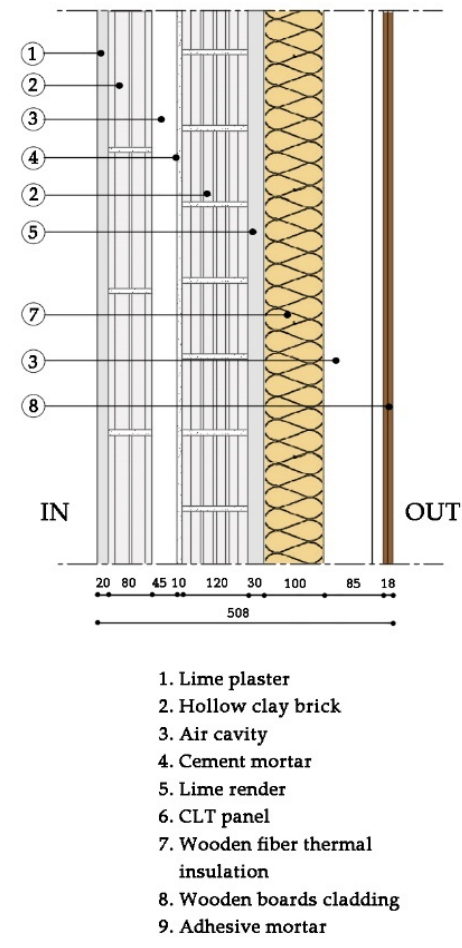

(b)

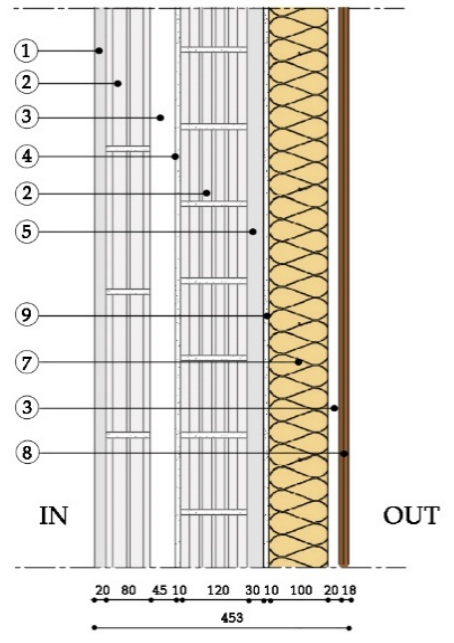

(c)

Figure 11. Stratigraphy $(\mathrm{mm})$ of the outer wall post-renovation with the addition of $(\mathbf{a}, \mathbf{b})$ prefabricated timber panels (PTP): (a) structural CLT panel, (b) non-structural wooden-framed panel; and (c) external thermal insulation composite system (ETICS).

Then, the second simulation considered the addition of an external thermal insulation composite system (ETICS) to the current outer walls in order to compare the proposed integrated renovation intervention with a traditional retrofit system in terms of energy savings. The ETICS included a 10-cm-thick wooden fiber insulation layer $\left(\rho=50 \mathrm{~kg} \mathrm{~m}^{-3} ; \lambda=0.038 \mathrm{~W} \mathrm{~m}^{-1} \mathrm{~K}^{-1}\right)$ with the same above-mentioned cladding materials (Figure 11c) and showed the same U-value as the proposed integrated retrofit solution. Finally, in both cases, the building renovation included new wooden-framed double-glazing windows to replace the existing ones.

The thermal performance of the different retrofit solutions for the outer walls was also compared by looking at the values of the dynamic parameter, as detailed in the following section.

Both retrofit solutions regarding the building envelope were also investigated in combination with the roof thermal insulation. Specifically, a 10-cm-thick wooden fiber insulation layer $\left(\rho=120 \mathrm{~kg} \mathrm{~m}^{-3}\right.$; $\lambda=0.038 \mathrm{~W} \mathrm{~m}^{-1} \mathrm{~K}^{-1}$ ) was included on the attic floor of Block $\mathrm{A}$ and on the flat roof of Block B. Indeed, when approaching the energy retrofit of an existing building, it is highly advisable to involve the entire building envelope. If the energy retrofit also includes modifications to the heating systems, such an integrated approach may also become unavoidable in order to comply with the strict limitations on the primary energy consumption introduced by Italian regulations [33].

The U-values of the main building components before and after renovation are reported in Table 1. $\mathrm{U}$-values after renovation comply with the limits set by the current regulations for the climatic zone $\mathrm{B}$ (Catania).

The simulations included a natural ventilation rate of $2 \mathrm{ACH}$ when the outdoor temperature was between $20^{\circ} \mathrm{C}$ and $26^{\circ} \mathrm{C}$ in order to account for the behavior of the occupants who tend to open windows for air renewal, but only if the outdoor conditions are favorable. In addition, a constant infiltration rate of $0.0007 \mathrm{~m}^{3} \mathrm{~s}^{-1} \mathrm{~m}^{-2}$ was considered: this value was halved for the post-renovation simulations due to the lower permeability of the new windows. Internal loads related to lighting 
$\left(1 \mathrm{~W} \mathrm{~m}^{-2}\right)$ and occupancy were also considered. Finally, the simulations were run by applying an ideal HVAC system that was constantly able to keep the indoor air temperature at the desired level: in particular, the indoor set-point temperature for the heating and cooling season was set to $20^{\circ} \mathrm{C}$ and $26{ }^{\circ} \mathrm{C}$, respectively. The simulations were run over the whole year, from January to December: the output consisted of a sequence of hourly values for the heating and cooling power of the ideal HVAC system, which was then integrated in order to calculate the overall seasonal energy demand.

Table 1. U-Value of the main building components (according to the standard UNI 11300 [34] and UNI 10077 [35]).

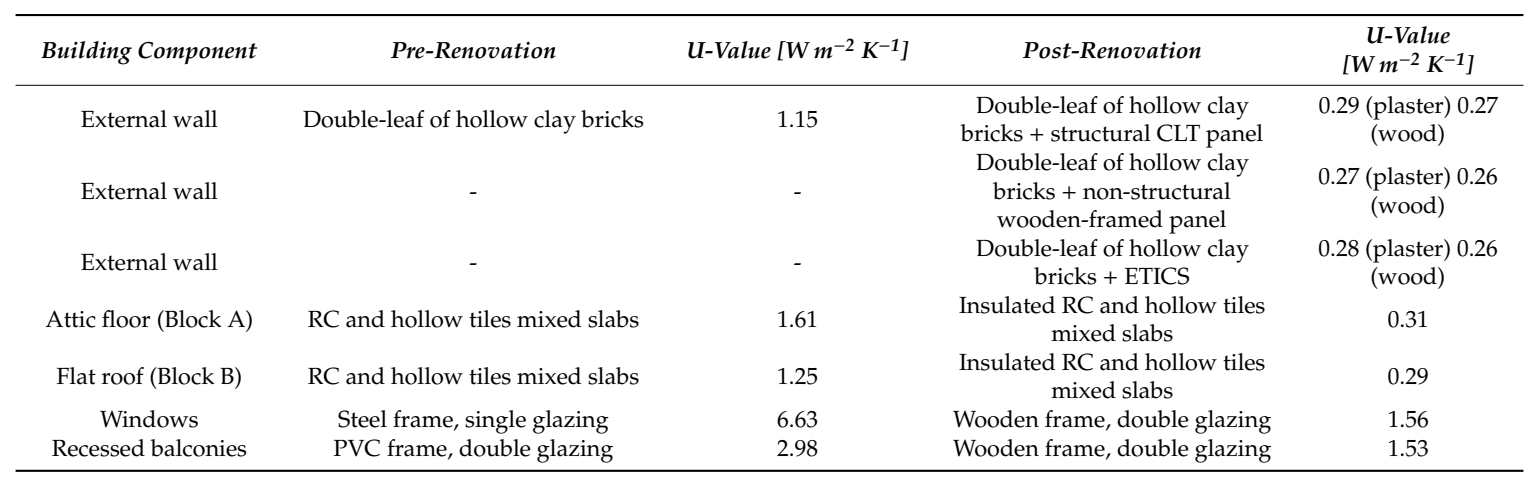

\section{Results}

Table 2 reports the stationary and dynamic parameters that quantify the thermal performance of the outer walls, before and after both interventions, i.e., the proposed integrated PTP-based retrofitting solution and the traditional ETICS application. In addition to the $U$-value, the compared parameters were the periodic thermal transmittance $\left(\mathrm{Y}_{\mathrm{IE}}\right)$, decrement factor $\left(\mathrm{f}_{\mathrm{a}}\right)$, time shift $(\varphi)$, internal areal heat capacity $\left(\kappa_{\mathrm{i}}\right)$, and surface mass $\left(\mathrm{M}_{\mathrm{s}}\right)$.

Table 2. Stationary and dynamic thermal performance of the outer walls, before and after both the integrated PTP-based retrofitting intervention and the traditional energy one based on the ETICS. (calculation according to the algorithms reported in ISO Standard 13786 [36]).

\begin{tabular}{|c|c|c|c|c|c|c|c|}
\hline \multicolumn{2}{|l|}{ Current State } & \multicolumn{4}{|c|}{ PTP } & \multicolumn{2}{|c|}{ ETICS } \\
\hline & & \multicolumn{2}{|c|}{ Plaster } & \multicolumn{2}{|c|}{ Wood } & \multirow[t]{2}{*}{ Plaster } & \multirow[t]{2}{*}{ Wood } \\
\hline & & $S T^{1}$ Panel & NST $^{1}$ Panel & $S T^{1}$ Panel & NST $^{1}$ Panel & & \\
\hline 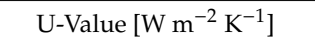 & 1.15 & 0.29 & 0.27 & 0.27 & 0.26 & 0.28 & 0.26 \\
\hline $\mathrm{Y}_{\mathrm{IE}}\left[\mathrm{W} \mathrm{m}^{-2} \mathrm{~K}^{-1}\right]$ & 0.49 & 0.013 & 0.019 & 0.012 & 0.019 & 0.024 & 0.022 \\
\hline Decrement factor, $\mathrm{f}_{\mathrm{a}}[-]$ & 0.43 & 0.04 & 0.07 & 0.04 & 0.07 & 0.09 & 0.08 \\
\hline Time shift, $\varphi[\mathrm{h}]$ & 8.3 & 17.34 & 15.53 & 17.09 & 15.26 & 12.6 & 13.15 \\
\hline $\begin{array}{l}\text { Internal areal heat capacity, } \\
\qquad \mathrm{k}_{1}\left[\mathrm{KJ} \mathrm{m} \mathrm{m}^{-2} \mathrm{~K}^{-1}\right]\end{array}$ & 54.15 & 47.36 & 47.38 & 47.37 & 47.39 & 47.6 & 47.54 \\
\hline Surface mass, $\mathrm{M}_{\mathrm{S}}\left[\mathrm{kg} \mathrm{m}^{-2}\right]$ & 202.04 & 247.29 & 229 & 256.29 & 223.04 & 207.04 & 216.04 \\
\hline
\end{tabular}

Under the assumption of a cyclic temperature excitation acting on the outer side of the wall, the periodic thermal transmittance $\mathrm{Y}_{\mathrm{IE}}$ is the ratio between the amplitude of the two cyclic functions describing the incoming heat flux and the temperature excitation, respectively. According to the current Italian regulation [33], the outer walls must have $\mathrm{Y}_{\mathrm{IE}}<0.10 \mathrm{~W} \mathrm{~m}^{-2} \mathrm{~K}^{-1}$, both in new and renovated buildings, except for the walls facing north.

The decrement factor $f_{a}$ is the ratio of the periodic to the stationary thermal transmittance, while the time shift $\varphi$ is the time lag between the peak outside temperature and the peak heat flux transferred indoors. Walls with $\varphi>10 \mathrm{~h}$ and $\mathrm{f}_{\mathrm{a}} \leq 0.30$ have good dynamic thermal performance.

The internal areal heat capacity $\kappa_{i}$ describes the capability of a wall to accumulate heat after a cyclic temperature fluctuation occurring on its inner side. A wall with high internal areal heat capacity 
helps to attenuate the indoor overheating produced by intense heat gains, thus improving the indoor thermal comfort in summer [37]. According to some studies, $\mathrm{K}_{\mathrm{i}}>50 \mathrm{~kJ} \mathrm{~m}^{-2} \mathrm{~K}^{-1}$ can be regarded as a good performance level [38].

Finally, the surface mass $M_{s}$ is the mass per unit wall surface, which positively influences the thermal inertia of the wall. According to the Italian regulation [33], the outer walls should have $\mathrm{M}_{\mathrm{s}}>230 \mathrm{~kg} / \mathrm{m}^{2}$.

As shown in Table 2, both renovation solutions ensured excellent dynamic thermal performance in terms of the decrement factor $\left(f_{a}<0.15\right)$ and time shift $(\varphi>12 h)$ and complied with the current Italian regulation regarding the periodic thermal transmittance $\left(\mathrm{Y}_{\mathrm{IE}}<0.10 \mathrm{~W} \mathrm{~m}^{-2} \mathrm{~K}^{-1}\right)$. Specifically, the proposed PTP-based system provided the highest time shift value, which increased by 9 and $7 \mathrm{~h}$ with structural and non-structural prefabricated panels, respectively (compared to the 5-h increase with traditional energy retrofit). The decrement factor and the periodic thermal transmittance were also lower than for the ETICS solution, while the surface mass considerably increased and became higher than $230 \mathrm{~kg} \mathrm{~m}^{-2}$ in the case of structural panels (ST). These first results show the potential of the proposed integrated system to improve the indoor thermal comfort, also compared to the traditional energy retrofitting intervention based on ETICS application.

Table 3 also reports the stationary and dynamic performance of the attic floor (Block A) and flat roof (Block B) at the pre- and post-renovation state. The periodic thermal transmittance showed a drastic reduction and now complied with the Italian regulation, i.e., $\mathrm{Y}_{\mathrm{IE}}<0.18 \mathrm{~W} \mathrm{~m}^{-2} \mathrm{~K}^{-1}$ for the horizontal envelope components.

Table 3. Stationary and dynamic thermal performance of the attic floor (Block A) and flat roof (Block B), pre- and post-renovation (calculation according to the algorithms reported in ISO Standard 13786 [36]).

\begin{tabular}{ccccc}
\hline & \multicolumn{2}{c}{ Current State } & \multicolumn{2}{c}{ Post-Renovation State } \\
\hline & Block $\boldsymbol{A}$ & Block $\boldsymbol{B}$ & Block $\boldsymbol{A}$ & Block $\boldsymbol{B}$ \\
\hline $\mathrm{U}-$ Value $\left[\mathrm{W} \mathrm{m}^{-2} \mathrm{~K}^{-1}\right]$ & 1.61 & 1.25 & 0.31 & 0.29 \\
$\mathrm{Y}_{\mathrm{IE}}\left[\mathrm{W} \mathrm{m}{ }^{-2} \mathrm{~K}^{-1}\right]$ & 0.56 & 0.2 & 0.037 & 0.013 \\
Decrement factor, $\mathrm{f}_{\mathrm{a}}[-]$ & 0.35 & 0.16 & 0.12 & 0.05 \\
Time shift, $\varphi[\mathrm{h}]$ & 9.13 & 12.96 & 14.79 & 18.64 \\
Internal areal heat capacity, $\mathrm{k}_{1}\left[\mathrm{KJ} \mathrm{m}^{-2} \mathrm{~K}^{-1}\right]$ & 73.4 & 67.94 & 66.07 & 65.54 \\
Surface mass, $\mathrm{M}_{\mathrm{s}}\left[\mathrm{kg} \mathrm{m}^{-2}\right]$ & 368 & 522.2 & 380 & 534.2 \\
\hline
\end{tabular}

Figure 12 shows the results of the dynamic energy simulations in terms of heating, cooling, and global energy needs per unit net useful surface $\left(\mathrm{kWh} \mathrm{m}^{-2}\right)$ of both blocks, at the pre- and post-renovation state. Since EnergyPlus cannot simulate thermal bridges, their contribution to the energy needs was considered by adding $10 \%$ and $5 \%$ to the results of the total heating and cooling needs, respectively. The percent addition to the heating needs was in line with the value suggested by UNI 11300 Standard for an existing non-insulated RC-framed building [39]; in this study, this percentage was also applied to the refurbished building, which is reasonable if thermal bridges are suitably corrected in the design stage. In the summer, thermal bridges have a lower impact since heat losses have a minor role in the calculation of the cooling energy needs if compared to internal and solar heat gains. Further investigations based on 2D numerical models will provide a more precise estimation of the heat losses due to thermal bridges after renovation.

The results reported in Figure 12 indicate that the proposed integrated retrofitting solution significantly improved the energy performance of the selected building, especially in the winter. In fact, in Blocks A and B, the energy demand for heating was reduced by $65 \%$ and $70 \%$, respectively. In detail, $7.02 \mathrm{kWh} \mathrm{m}^{-2}$ and $6.84 \mathrm{kWh} \mathrm{m}^{-2}$ were the heating needs of Block A with plaster and wood as cladding materials, respectively (compared to the current heating needs of $19.65 \mathrm{kWh} \mathrm{m}^{-2}$ ). In Block B, the current heating needs were $22.18 \mathrm{kWh} \mathrm{m}^{-2}$, and they decreased to $6.85 \mathrm{kWh} \mathrm{m}^{-2}$ and $6.48 \mathrm{kWh} \mathrm{m}^{-2}$ with plaster and wood cladding, respectively. In both blocks, the reduction of the energy 
demand for cooling was lower than that for heating. In particular, in Block $\mathrm{A}$ the current cooling needs (10.29 $\mathrm{kWh} \mathrm{m}^{-2}$ ) were reduced to $9.60 \mathrm{kWh} \mathrm{m}^{-2}$ (7\% savings) and $9.74 \mathrm{kWh} \mathrm{m}^{-2}$ (5\% savings) with plaster and wood cladding, respectively. In Block B the current cooling needs of $8.87 \mathrm{kWh} \mathrm{m}^{-2}$ fell to $6.93 \mathrm{kWh} \mathrm{m}^{-2}$ (22\% savings) and $7.11 \mathrm{kWh} \mathrm{m}^{-2}$ (20\% savings) for the above-mentioned solutions. Overall, the application of the proposed panels provided a reduction of the global energy demand by $44 \%$ in Block A and by $56 \%$ in Block B.

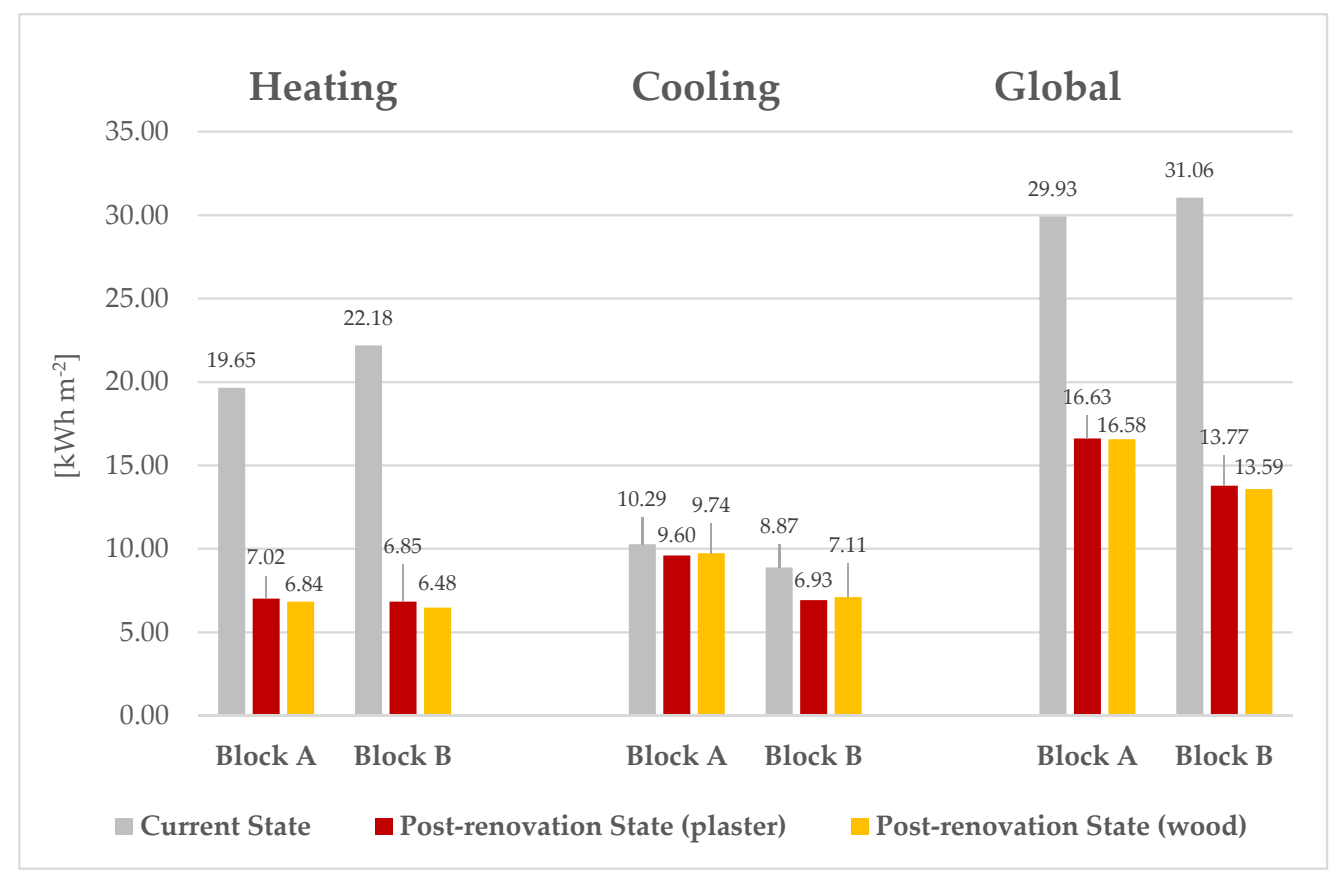

Figure 12. Heating, cooling, and global energy needs per unit net surface [ $\left.\mathrm{kWh} \mathrm{m}^{-2}\right]$ (Blocks A and B, before and after the proposed integrated PTP-based retrofitting intervention).

Tables 4 and 5 report the heating and cooling energy needs (per story and total) and the percentage of energy savings associated both with the proposed integrated PTP-based retrofitting intervention and the traditional energy retrofit solution (ETICS). For both interventions, the contribution of the additional roof thermal insulation action is also reported.

Table 4. Heating energy needs (per story and total) and percentage of energy savings before and after both the integrated PTP-based retrofitting intervention and the traditional energy one based on the ETICS.

\begin{tabular}{|c|c|c|c|c|c|c|c|c|c|c|}
\hline \multirow{3}{*}{ Block } & \multirow{3}{*}{ Story } & \multicolumn{9}{|c|}{ Heating [kWh m-2] } \\
\hline & & \multirow[t]{2}{*}{ Current State } & \multicolumn{2}{|c|}{ PTP } & \multicolumn{2}{|c|}{ PTP + Insulated Roof } & \multicolumn{2}{|c|}{ ETICS } & \multicolumn{2}{|c|}{$\begin{array}{c}\text { ETICS + } \\
\text { Insulated Roof }\end{array}$} \\
\hline & & & Plaster & Wood & Plaster & Wood & Plaster & Wood & Plaster & Wood \\
\hline \multirow{5}{*}{$\mathbf{A}$} & II & 17.13 & 4.94 & 4.76 & 4.94 & 4.76 & 4.97 & 4.73 & 4.97 & 4.73 \\
\hline & III & 16.23 & 3.74 & 3.60 & 3.74 & 3.60 & 3.76 & 3.57 & 3.76 & 3.57 \\
\hline & $\mathrm{V}$ & 26.24 & 12.98 & 12.75 & 7.35 & 7.14 & 13.01 & 12.70 & 7.38 & 7.10 \\
\hline & TOTAL & 19.65 & 7.02 & 6.84 & 5.27 & 5.10 & 7.05 & 6.80 & 5.30 & 5.06 \\
\hline & \multicolumn{2}{|c|}{ Energy savings [\%] } & 64.26 & 65.19 & 73.15 & 74.05 & 64.13 & 65.38 & 73.03 & 74.23 \\
\hline \multirow{6}{*}{ B } & I & 22.70 & 5.41 & 4.98 & 5.40 & 4.96 & 5.43 & 4.95 & 5.41 & 4.94 \\
\hline & II & 18.34 & 3.64 & 3.35 & 3.64 & 3.35 & 3.66 & 3.33 & 3.66 & 3.33 \\
\hline & III & 18.22 & 3.86 & 3.56 & 3.86 & 3.56 & 3.87 & 3.54 & 3.87 & 3.54 \\
\hline & IV & 29.47 & 14.48 & 14.04 & 5.22 & 4.85 & 14.49 & 14.02 & 5.23 & 4.83 \\
\hline & TOTAL & 22.18 & 6.85 & 6.48 & 4.53 & 4.18 & 6.86 & 6.46 & 4.54 & 4.16 \\
\hline & \multicolumn{2}{|c|}{ Energy savings [\%] } & 69.13 & 70.79 & 79.59 & 81.17 & 69.07 & 70.87 & 79.52 & 81.25 \\
\hline
\end{tabular}


Table 5. Cooling energy needs (per story and total) and percentage of energy savings before and after both the integrated PTP-based retrofitting intervention and the traditional energy one based on the ETICS.

\begin{tabular}{|c|c|c|c|c|c|c|c|c|c|c|}
\hline \multirow{3}{*}{ Block } & \multirow{3}{*}{ Story } & \multicolumn{9}{|c|}{ Cooling $\left[\mathrm{kWh} \mathrm{m}^{-2}\right]$} \\
\hline & & \multirow[t]{2}{*}{ Current State } & \multicolumn{2}{|c|}{ PTP } & \multicolumn{2}{|c|}{ PTP + Insulated Roof } & \multicolumn{2}{|c|}{ ETICS } & \multicolumn{2}{|c|}{$\begin{array}{c}\text { ETICS + } \\
\text { Insulated Roof }\end{array}$} \\
\hline & & & Plaster & Wood & Plaster & Wood & Plaster & Wood & Plaster & Wood \\
\hline \multirow{5}{*}{$\mathbf{A}$} & II & 11.65 & 10.69 & 10.83 & 10.69 & 10.83 & 10.68 & 10.82 & 10.68 & 10.82 \\
\hline & III & 9.45 & 8.55 & 8.68 & 8.55 & 8.68 & 8.55 & 8.67 & 8.55 & 8.67 \\
\hline & $\mathrm{V}$ & 9.70 & 9.57 & 9.71 & 8.88 & 9.03 & 9.57 & 9.71 & 8.89 & 9.03 \\
\hline & TOTAL & 10.29 & 9.60 & 9.74 & 9.39 & 9.53 & 9.60 & 9.74 & 9.39 & 9.53 \\
\hline & \multicolumn{2}{|c|}{ Energy savings [\%] } & 6.63 & 5.30 & 8.70 & 7.35 & 6.65 & 5.34 & 8.72 & 7.40 \\
\hline \multirow{6}{*}{ B } & I & 8.44 & 5.88 & 6.04 & 5.88 & 6.04 & 5.86 & 6.00 & 5.86 & 6.00 \\
\hline & II & 8.59 & 6.76 & 6.94 & 6.76 & 6.94 & 6.75 & 6.90 & 6.75 & 6.90 \\
\hline & III & 8.78 & 7.10 & 7.29 & 7.10 & 7.29 & 7.10 & 7.25 & 7.10 & 7.25 \\
\hline & IV & 9.68 & 7.97 & 8.17 & 7.00 & 7.22 & 7.97 & 8.14 & 7.01 & 7.18 \\
\hline & TOTAL & 8.87 & 6.93 & 7.11 & 6.68 & 6.87 & 6.92 & 7.07 & 6.68 & 6.83 \\
\hline & \multicolumn{2}{|c|}{ Energy savings [\%] } & 21.95 & 19.90 & 24.68 & 22.58 & 22.02 & 20.33 & 24.75 & 23.04 \\
\hline
\end{tabular}

Overall, the two interventions on the envelope of the selected building were similar in terms of energy-needs reduction since the observed differences were below $1 \%$. The highest savings for heating were observed in the intermediate stories (around $80 \%$ ), while the lowest reduction referred to the upper stories $(50 \%)$. The percentage of energy savings for cooling was lower, with maximum values in the intermediate stories (around 10\% in Block A and 20\% in Block B). Finally, the concurrent addition of a thermal insulation layer on the attic floor of Block A and on the flat roof of Block B ensured a further reduction of the heating energy needs equal to $10 \%$, compared to the effects of the only envelope renovation actions.

These results confirm that the proposed integrated retrofitting system has a high potential for energy saving, which is comparable to a traditional ETICS system with the same U-value. However, the benefit of the first system consists of the possibility of also improving the seismic performance with the same intervention, thus reducing costs and time for an integrated multi-purpose effective renovation of the RC framed building stock.

\section{Conclusions}

This paper presents and describes an innovative and versatile renovation solution for RC framed buildings in terms of a technical-feasibility, energy-efficiency, and architectural-enhancement potential. The proposed solution consists of cladding the building envelope with a new tailorable skin based on prefabricated timber panels, which improve the energy and seismic performance as well as the architectural quality of the renovated buildings. The use of pre-assembled timber-based components and the external dry-installation allow reducing implementation costs and time, embodied energy, and occupants' disruption, resulting in a sustainable system from a social, economic, and environmental point of view.

Dynamic thermal simulations performed on the parametric model of a typical Italian RC framed apartment building located in Southern Italy, both pre- and post-renovation, confirmed that the proposed solution significantly reduces the energy demand. In particular, the overall annual energy needs for heating and cooling were decreased up to $56 \%$, while the highest energy savings were observed during winter heating in the intermediate stories. The comparison between the suggested integrated retrofitting intervention and a traditional solution based on an ETICS application showed that the two solutions were similar in terms of energy savings, while the dynamic thermal performance of the outer walls improved considerably with the addition of prefabricated timber panels. Finally, 
the concurrent roof thermal insulation could further reduce the heating energy needs of the selected building by $10 \%$.

Regarding the seismic behavior, the described CLT structural panels were conceived to overcome the typical deficiencies of most existing RC framed buildings located in earthquake-prone areas. Indeed, these panels, which are specifically equipped with friction dampers, can provide the existing structure with additional stiffness, strength, and energy dissipation capacity.

This research is only the preliminary stage of a more comprehensive research project: experimental investigations are currently ongoing to optimize the industrial replicability, structural efficiency, and durability of the presented friction damper, while numerical simulations will evaluate the heat transfer through the thermal bridges and the seismic performance of buildings upgraded with the proposed technique.

\section{Patents}

Margani, G.; Marino, E.M.; Tardo, C. (inventors); University of Catania (assignee). Dispositivo di connessione dissipativa per pannelli in legno a strati incrociati. Italian Patent 102019000012402, 19 July 2019.

Author Contributions: Conceptualization, G.M. and E.M.M.; case study and simulations, C.T.; supervision of constructive and architectural issues, G.M.; supervision of structural issues, E.M.M.; supervision of energy-efficiency issues, G.E.; writing—original draft, C.T.; writing—review and editing G.E., G.M., and E.M.M. All authors have read and agree to the published version of the manuscript.

Funding: This research received no external funding.

Acknowledgments: The authors would like to thank Sebastiano D'Urso for his support in the design of the case study and Martina Battiato for her contribution to the energy simulations and the images reported in Figures 7-9.

Conflicts of Interest: The authors declare no conflict of interest.

\section{References}

1. Sajn, N. Energy Efficiency of Buildings: A Nearly Zero-Energy Future. European Parliamentary Research Service, European Union. 2016. Available online: https://www.europarl.europa.eu/RegData/etudes/BRIE/2016/ 582022/EPRS_BRI(2016)582022_EN.pdf (accessed on 15 December 2019).

2. Eurostat. Energy Consumption in Households. Available online: https://ec.europa.eu/eurostat/statisticsexplained/index.php/Energy_consumption_in_households\#Energyproducts_used_in_the_residential_ sector (accessed on 15 December 2019).

3. BPIE (Buildings Performance Institute Europe). Available online: http://bpie.eu/wp-content/uploads/2017/ 12/State-of-the-building-stock-briefing_Dic6.pdf (accessed on 15 December 2019).

4. Economidou, M.; Laustsen, J.; Ruyssevelt, P.; Staniaszek, D. Europe's Buildings Under the Microscope; BPIE: Brussels, Belgium, 2011; ISBN 9789491143014.

5. Artola, I.; Rademaekers, K.; Williams, R.; Yearwood, J. Boosting Building Renovation: What Potential and Value for Europe; European Parliament: Brussels, Belgium, 2016.

6. La Greca, P.; Margani, G. Seismic and Energy Renovation Measures for Sustainable Cities: A Critical Analysis of the Italian Scenario. Sustainability 2018, 10, 254. [CrossRef]

7. Seismic Hazard Harmonization in Europe (SHARE). European Seismic Hazard Map. 2013. Available online: http://www.share-eu.org/sites/default/files/SHARE_Brochure_public.web_.pdf (accessed on 15 December 2019).

8. Belleri, A.; Marini, A. Does seismic risk affect the environmental impact of existing buildings? Energy Build. 2016, 110, 149-158. [CrossRef]

9. Reid Middleton. Central Mexico Earthquake Reconnaissance. Available online: http://www.reidmiddleton. com/reidourblog/central-mexico-earthquake-reconnaissance-day-3/ (accessed on 12 February 2020).

10. Power, A. Housing and sustainability: Demolition or refurbishment? Proc. Inst. Civ. Eng. Urban Des. Plan. 2010, 163, 205-216. [CrossRef]

11. Alshamrani, O.S.; Galal, K.; Alkass, S. Integrated LCA-LEED sustainability assessment model for structure and envelope systems of school buildings. Build. Environ. 2014, 80, 61-70. [CrossRef] 
12. Alba-Rodríguez, M.D.; Martínez-Rocamora, A.; Vallejo, P.G.; Sánchez, A.F.; Marrero, M. Building rehabilitation versus demolition and new construction: Economic and environmental assessment. Environ. Impact Assess. Rev. 2017, 66, 115-126. [CrossRef]

13. Chandrakar, J.; Singh, A.K. Study of Various Local and Global Seismic Retrofitting Strategies-A review. Int. J. Eng. Res. Technol. 2017, 6, 824-831. [CrossRef]

14. Bournas, D. Innovative Materials for Seismic and Energy Retrofitting of the Existing EU Buildings; EUR 29184 EN; Publications Office of the European Union: Luxembourg, 2018.

15. Bai, J. Advanced Fibre-Reinforced Polymer (FRP) Composites for Structural Applications; Woodhead Publishing: Sawston, Cambridge, UK, 2013. [CrossRef]

16. Lau, D.; Qiu, Q.; Zhou, A.; Chow, C.L. Long term performance and fire safety aspect of FRP composites used in building structures. Constr. Build. Mater. 2016, 126, 573-585. [CrossRef]

17. Tetta, Z.C.; Koutas, L.; Bournas, D.A. Textile-reinforced mortar (TRM) versus fiber-reinforced polymers (FRP) in shear strengthening of concrete beams. Compos. Part B Eng. 2015, 77, 338-348. [CrossRef]

18. Rahimi, A.; Maheri, M.R. The effects of steel X-brace retrofitting of RC frames on the seismic performance of frames and their elements. Eng. Struct. 2020, 206, 110149. [CrossRef]

19. Mazza, F.; Pucci, D. Static vulnerability of an existing r.c. structure and seismic retrofitting by CFRP and base-isolation: A case study. Soil Dyn. Earthq. Eng. 2016, 84, 1-12. [CrossRef]

20. Bournas, D.A. Concurrent seismic and energy retrofitting of RC and masonry building envelopes using inorganic textile-based composites combined with insulation materials: A new concept. Compos. Part B Eng. 2018, 148, 166-179. [CrossRef]

21. Ecosism. Geniale Cappotto Sismico. Available online: http://www.ecosism.com/moduli/geniale/ (accessed on 20 December 2019).

22. Pertile, V.; De Stefani, L.; Scotta, R. Development and characterization of a system for the seismic and energy retrofit of existing buildings. Procedia Struct. Integr. 2018, 11, 347-354. [CrossRef]

23. Artino, A.; Evola, G.; Margani, G.; Marino, E.M. Seismic and Energy Retrofit of Apartment Buildings through Autoclaved Aerated Concrete (AAC) Blocks Infill Walls. Sustainability 2019, 11, 3939. [CrossRef]

24. Ferrante, A.; Mochi, G.; Predari, G.; Badini, L.; Fotopoulou, A.; Gulli, R.; Semprini, G. A European Project for Safer and Energy Efficient Buildings: Pro-GET-onE (Proactive Synergy of inteGrated Efficient Technologies on Buildings' Envelopes). Sustainability 2018, 10, 812. [CrossRef]

25. Marini, A.; Passoni, C.; Belleri, A.; Feroldi, F.; Preti, M.; Metelli, G.; Riva, P.; Giuriani, E.; Plizzari, G. Combining seismic retrofit with energy refurbishment for the sustainable renovation of RC buildings: A proof of concept. Eur. J. Environ. Civ. Eng. 2017, 21, 1-21. [CrossRef]

26. D'Urso, S.; Cicero, B. From the Efficiency of Nature to Parametric Design. A Holistic Approach for Sustainable Building Renovation in Seismic Regions. Sustainability 2019, 11, 1227. [CrossRef]

27. Manfredi, V.; Masi, A. Seismic Strengthening and Energy Efficiency: Towards an Integrated Approach for the Rehabilitation of Existing RC Buildings. Buildings 2018, 8, 36. [CrossRef]

28. Sustersic, I.; Dujic, B. Seismic shaking table testing of a reinforced concrete frame with masonry infill strenghtened with cross laminated timber panels. In Proceedings of the World Conference on Timber Engineering, Quebec, QC, Canada, 10-14 August 2014.

29. Stazi, F.; Serpilli, M.; Maracchini, G.; Pavone, A. An experimental and numerical study on CLT panels used as infill shear walls for RC buildings retrofit. Constr. Build. Mater. 2019, 211, 605-616. [CrossRef]

30. Brandner, R.; Flatscher, G.; Ringhofer, A.; Schickhofer, G.; Thiel, A. Cross laminated timber (CLT): Overview and development. Eur. J. Wood Wood Prod. 2016, 74, 331-351. [CrossRef]

31. Presutti, A.; Evangelista, P. Edifici Multipiano in Legno a Pannelli Portanti in XLAM; Dario Flaccovio Editore: Palermo, Italy, 2014; p. 36.

32. Poggio, T.; Boreiko, D. Social Housing in Italy: Old Problems, Older Vices and Some New Virtues? Crit. Hous. Anal. 2017, 4, 112-123. [CrossRef]

33. Inter-Ministerial Decree 26.6.2015. In Adeguamento Linee Guida Nazionali per la Certificazione Energetica Degli Edifici; Allegato 1; Gazzetta Ufficiale della Repubblica Italiana n.162 del 15.7.2015: Rome, Italy, 2015.

34. Ente nazionale italiano di unificazione. Prestazioni Energetiche Degli Edifici Parte 1: Determinazione del Fabbisogno di Energia Termica Dell'edificio per la Climatizzazione Estiva ed Invernale. In UNI/TS 11300-1; UNI: Roma, Italy, 2014. 
35. Ente nazionale italiano di unificazione. Prestazione Termica di Finestre, Porte e Chiusure Oscuranti-Calcolo Della Trasmittanza Termica. In UNI 10077-1; UNI: Roma, Italy, 2018.

36. International Organization for Standardization. Thermal performance of building components. Dynamic thermal characteristics. Calculation methods. In ISO 13786; ISO: Geneva, Switzerland, 2017.

37. Cascone, S.; Evola, G.; Gagliano, A.; Sciuto, G.; Parisi, C.B. Laboratory and In-Situ Measurements for Thermal and Acoustic Performance of Straw Bales. Sustainability 2019, 11, 5592. [CrossRef]

38. Stazi, F.; Ulpiani, G.; Pergolini, M.; Di Perna, C. The role of areal heat capacity and decrement factor in case of hyper insulated buildings: An experimental study. Energy Build. 2018, 176, 310-324. [CrossRef]

39. Ente nazionale italiano di unificazione. Prestazioni Energetiche Degli Edifici Parte 1: Determinazione del Fabbisogno di Energia Termica Dell'edificio per la Climatizzazione Estiva ed Invernale. In UNI/TS 11300-1; UNI: Roma, Italy, 2008.

(C) 2020 by the authors. Licensee MDPI, Basel, Switzerland. This article is an open access article distributed under the terms and conditions of the Creative Commons Attribution (CC BY) license (http://creativecommons.org/licenses/by/4.0/). 